\title{
Food patches and a surface deposit feeding spionid polychaete
}

\author{
Rebecca L. Kihslinger*, Sarah A. Woodin** \\ Marine Science Program, University of South Carolina, Columbia, South Carolina 29208, USA
}

\begin{abstract}
Surface deposit feeders live in an environment in which nutritional states change rapidly due to flux of surface material. This project addressed the question of foraging choice by a common spionid deposit feeder, Streblospio benedicti. Individuals of $S$. benedicti were offered both organically enriched sediment and unaltered sediment simultaneously as feeding choices. Three organic conditions along with the worms' natural sediment were employed in the choice experiments. The natural sediment had an organic content of $1.5 \%$. Organic enrichments were prepared by adding $0,2,4$, or $8 \%$ by weight of an organically enriched substance to natural sediment, which resulted in final organic contents of $1.5,4.6,6.9$, and $12.1 \%$ organic matter respectively. The worms were videotaped for $30 \mathrm{~min}$ each. Feeding was measured as time spent collecting particles on one or the other of the sediment additions. With increasing organic enrichment the worms consistently chose to forage on the enriched sediments and concomitantly reduced their likelihood of major tissue loss by reducing their degree of exposure while foraging. On unenriched sediments worms enlarged their foraging area by increasing their exposure of body segments as well as tentacles, thus also increasing their predation risk. The switches in foraging locale and degree of pre-ingestion sorting with enrichment indicate selectivity on a small spatial scale.
\end{abstract}

KEY WORDS: Deposit feeding $\cdot$ Optimal foraging $\cdot$ Risk $\cdot$ Polychaete $\cdot$ Macrofauna $\cdot$ Infauna

\section{INTRODUCTION}

Deposit feeding is one of the most widely used trophic modes of organisms living in aquatic sediments, both marine and freshwater. These organisms employ a microphagous feeding strategy that involves collecting and ingesting large volumes of sediment. The quality of food found in these sediments is at best patchy in both space and time (Lopez \& Levinton 1987. Mayer et al. 1993). The foraging behavior of aquatic organisms and their ability to alter behavior in response to changing feeding conditions are therefore of utmost importance. The data to date indicate that deposit feeders respond to changing feeding conditions by differential ingestion (Dade et al. 1993) and by particle selection based on a combination of factors including particle size (Self \& Jumars 1988), density,

\footnotetext{
${ }^{* *}$ Present address: Center for Animal Behavior, One Shields Avenue, University of California, Davis, California 95616, USA ${ }^{* *}$ Corresponding author. E-mail: woodin@biol.sc.edu
}

organic enrichment, specific gravity (Self \& Jumars 1978) and food quality (see reviews by Lopez \& Levinton 1987 and Jumars 1993). In addition, foraging methods may change as a function of browsing predation (Lindsay \& Woodin 1995), while deposit-feeder choices, particularly of particle size, may change ontogenetically (Shimeta 1996, Hentschel 1996, 1998).

Given that some deposit feeders can respond to both food characteristics and predation risk, optimal foraging theory may apply. Optimal foraging theory assumes that fitness, the capacity of an organism to survive and transmit its genotype to future generations, is related to energy gain and predation risk (i.e. death rates and rates of tissue loss) (MacArthur \& Pianka 1966, Schoener 1971). Organisms are often expected to be primarily either energy maximizers or time minimizers (MacArthur 1972). The majority of the examples of optimal foraging theory involve mobile foragers; in contrast, most surface deposit feeders are sedentary or sessile. Holling (1959) defined foraging behavior as choices made in a patchy habitat. Working 
with mobile predators, his expectation was that predators would spend more time in patches of high prey density. Sediments are typically low in organic content; even organically rich sediment can contain as much as 95\% inorganic matter (Lopez \& Levinton 1987). Additionally, the sediment surface, the foraging area of surface deposit feeders, is in a continuous state of flux (Eckman \& Nowell 1984, Sun et al. 1997), such that patches of high food quality may exist for only short temporal periods (Miller et al. 1984, Bock \& Miller 1995). Fresh detrital material, for example, is typically of higher quality (higher energy availability) than the sediment grains themselves but is less dense and thus more prone to physical redistribution (Jumars 1993). For this reason, in order to maximize fitness, deposit feeders must take advantage of high quality food items while they are available. Due to temporal flux of food, even sedentary deposit feeders are able to make choices by altering their ingestion rates (Taghon \& Jumars 1984, Jumars \& Self 1986, Taghon \& Green 1990, Karrh \& Miller 1994, 1996); however, cm-scale spatial patch choice has yet to be measured.

Here the behavior of a surface deposit feeder relative to the organic content of the surface was examined. Streblospio benedicti is a tube-building, estuarine spionid polychaete found on the east and west coasts of the United States as well as in Europe. The animal, a deposit feeder, makes use of long tentaclelike palps to bring sediment to its mouth for ingestion. When the worms are under conditions of flow, individuals spend about $80 \%$ of their feeding time suspension feeding with their palps held rigidly into the water mass (Dauer 1984). However, in conditions of little or no flow $\left(<2 \mathrm{~cm} \mathrm{~s}^{-1}\right) S$. benedicti switches feeding strategies from suspension feeding to deposit feeding (Taghon 1992). In our experimental setup the individuals were forced to deposit feed. Spionids are easily observed while feeding and are known to respond to a variety of chemical cues (Ferner \& Jumars 1999), making them an excellent choice for such feeding experiments.

Individuals of Streblospio benedicti were exposed simultaneously to 2 sediment types, one low in organic content $(1.5 \%)$ and one elevated in organic content. We recorded the time individual worms spent on each sediment type and the degree of exposure of their anterior segments beyond the tube opening. Our predictions were as follows:

(1) Individuals of Streblospio benedicti would forage for a smaller percentage of the time on sediment of lower organic content than on sediment of higher organic content, due to both the higher energy gain from organically enriched sediment and the need to exploit high quality food in a temporally variable trophic environment. We expected this pattern to be more pronounced as the level of organic enrichment increased. This implies an ability to distinguish among items of different food quality; some surface deposit feeders are known to be able to differentiate between glass beads with an organic coating and those without (Taghon 1982, Clements \& Stancyk 1984).

(2) When worms feed on organically enriched sediments, a single tentacle foraging event on the sediment surface may bring large amounts of detrital material to the tube opening. In this case we would expect an increase in the amount of time spent in sorting material.

(3) Finally, because of our experimental design where both sediment types are within the palp length of the individual, we expected individuals to expose their anterior segments beyond the opening of the tube less as organic content increased. This reduces an individual's risk of tissue loss to predators such as fish (DeGroot 1971). This prediction implicitly assumes that body extension onto the sediment surface is a means by which individuals increase their foraging area under conditions of low food availability adjacent to the tube. It also assumes that body extension increases the probability of lethal predation or loss of a greater proportion of the palps than when there is no exposure of the anterior segments (Lindsay \& Woodin 1995).

\section{MATERIALS AND METHODS}

Animal collection and maintenance. Streblospio benedicti were collected in undisturbed cores $(6 \mathrm{~cm}$ inner diameter [i.d.] by $7 \mathrm{~cm}$ tall) from a muddy sand habitat at Oyster Landing in the North Inlet Estuary,

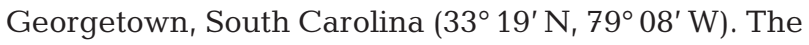
cores were maintained in a recirculating tank at $20^{\circ} \mathrm{C}$ under conditions where the surficial diatom layer persisted. Worms were collected on 3 dates in the fall of 1997 (September 13 and 27, November 4), and were used within 4 wk of collection. All treatments were randomized and were conducted from September 23 to November 18, 1997. Only isolated worms were used in the experiments in order to avoid interactions with other animals.

Choice experiments. Individuals were videotaped in their original sediment cores in a constant temperature water bath at approximately $21^{\circ} \mathrm{C}$. Video was used in these experiments in order to gain an accurate account of long periods of behavior. A low-light, high resolution video camera (Javelin JE7362) was used with a $100 \mathrm{~mm}$ lens for a $35 \mathrm{~mm}$ camera. Illumination was provided by a red fiberlight. The setup was surrounded by black plastic in order to shield the experimental worms from unwanted light and was insulated from vibration to the extent possible. 
Prior to the addition of treatment sediments to the core, a layer of calcium carbonate was added to the area around the tube of the worm. This was done in order to obtain a clean surface on which to add material and to have a readily visible signal of depletion of the experimental surface prior to termination. The worms never exposed the calcium carbonate layer during the feeding observations. The opening of the individual's tube was then placed in the center of the viewing area. On average the viewing area was approximately 3 to 4 times the palp length of the experimental worm. Two millimeters of natural sediment was placed over one half of the viewing area, while an equivalent depth of 1 of 4 organically enriched sediments was placed over the other half of the viewing area. Thus, worms had equal access to both patches of food. The $30 \mathrm{~min}$ observation period began when the individual reappeared at the mouth of its tube and began to feed after the experimental preparation of the sediment surface. Feeding choice was measured by time spent collecting particles in the 2 areas.

Four levels of organic enrichment along with the worms' natural sediment were employed in the choice experiments. The additions were prepared using unsieved natural sediment mixed with a known amount of organic matter. The natural sediment had an organic content of $1.5 \%$. Addition experiments were prepared by adding $0,2,4$, or $8 \%$ by weight of Gerber Mixed Cereal for Baby ${ }^{\odot}$ to natural sediment (Taghon 1988). All organic contents were determined by loss on ignition at $500^{\circ} \mathrm{C}$. The 4 organic enrichments were found to contain 1.5, 4.6, 6.9, and $12.1 \%$ organic matter. Eight independent replicates were conducted for each treatment, yielding a total of 32 trials.

Each experimental addition was a mixture of approximately $5 \mathrm{~g}$ sediment, the desired percent by weight of baby food, and $5 \mathrm{ml}$ of seawater. The baby food was ground using a mortar and pestle and both very fine and remaining coarse particles were removed by sieving the material before it was weighed and added to the natural sediment. The organic material that passed through a $253 \mu \mathrm{m}$ sieve, but was retained on a $153 \mu \mathrm{m}$ sieve, was added as food. This was done in order to maintain equal grain size across treatments. A post-experiment grain size analysis was performed in order to determine that food quality and not grain size caused the results. The grain size analysis was performed by comparing the size of 20 randomly selected sediment grains from the $0 \%$ treatment to 20 grains from the $8 \%$ treatment (which included cereal grains). A paired $t$-test showed no significant differences in grain size between enriched and natural sediment ( $t=2.132, \mathrm{p}=0.406, \mathrm{n}=5$ ); specific gravity was probably reduced. Sediment, baby food, and seawater were mixed to a uniform consistency and then placed evenly onto the surface of the core with a spoon. The natural sediment addition was mixed with seawater to a uniform consistency and was also placed on the surface of the core with a spoon. Total sediment addition covered approximately $1 \mathrm{~cm}^{2}$ of the total surface area of the core. In all cases the sediment used in the additions was natural surficial sediment collected on a single date (September 13, 1997) from the top $2 \mathrm{~mm}$ of the worms' habitat in North Inlet Estuary, Georgetown, South Carolina. These sediments were mixed, divided into small bags and frozen at $-20^{\circ} \mathrm{C}$ until use.

Data analysis and statistics. The behavior of each individual was divided into the categories given in Table 1. Data were analyzed by the Kruskal-Wallis 1-way analysis of variance by ranks followed by a compatible multiple comparison test (Daniel 1990).

Table 1. Observed behaviors. Behaviors characterized as foraging behaviors included collecting on natural sediment, collecting on enriched sediment, sorting, and predation risk behavior. All other observed behaviors are characterized as non-foraging behaviors. Note that these categories are not mutually exclusive. For example, individuals typically only exposed their anterior segments while feeding

\begin{tabular}{|lll|}
\hline Behavior & Description & Foraging/non-foraging \\
\hline Collecting on natural sediment & $\begin{array}{l}\text { Percentage of time spent feeding on the natural } \\
\text { sediment addition } \\
\text { Cellecting on enriched sediment } \\
\text { Percentage of time spent feeding on the enriched } \\
\text { sediment addition } \\
\text { Visible and sorting clumps of detritus at the tube opening } \\
\text { but without tentacles on the sediment surface } \\
\text { Anterior segments exposed beyond the opening of the }\end{array}$ & Foraging \\
tube & $\begin{array}{l}\text { Foraging (worm was always } \\
\text { feeding when anterior } \\
\text { segments were exposed) }\end{array}$ \\
Defecation & Tentacles moving in the water column & $\begin{array}{l}\text { Non-foraging } \\
\text { Searching }\end{array}$ \\
Not visible & Withdrawn in the tube & $\begin{array}{l}\text { Non-foraging } \\
\text { Non-foraging }\end{array}$
\end{tabular}


When using the multiple comparison test, $\alpha$ was modified from 0.05 to 0.014 according to Lehmann's experimentwise error adjustment (Lehmann 1975).

All data on aspects of foraging were normalized because the percentages of the observation period spent collecting (bringing particles to the mouth), foraging (collecting time plus sorting time), and the total time visible were quite variable among individuals. Data were normalized by each individual's total foraging time in order to partition the components of foraging and to reduce the impact of non-foraging components on the normalization. Normalization was accomplished by dividing the time spent by an individual on an aspect of foraging by that individual's total foraging time (i.e. collecting plus sorting).

\section{RESULTS}

The percentage of the observation period spent collecting, actually carrying particles to the mouth, did not change with organic enrichment (Kruskal-Wallis, $p=0.83$ ). There was also no change in the percentage of the observation period devoted to all aspects of foraging by worms as organic enrichment increased (Fig. 1) (Kruskal-Wallis, $\mathrm{p}=0.60$ ) or in the percentage of time individuals were visible as a function of organic enrichment (Fig. 2) (Kruskal-Wallis, $\mathrm{p}=0.76$ ). In these experiments foraging is the time spent collecting plus the time spent sorting material at the mouth (Table 1). Search time, time spent waving palps in the water column, is not included in foraging time because no particles were brought to the mouth for ingestion while this behavior was exhibited. The percentage of the observation period spent on other

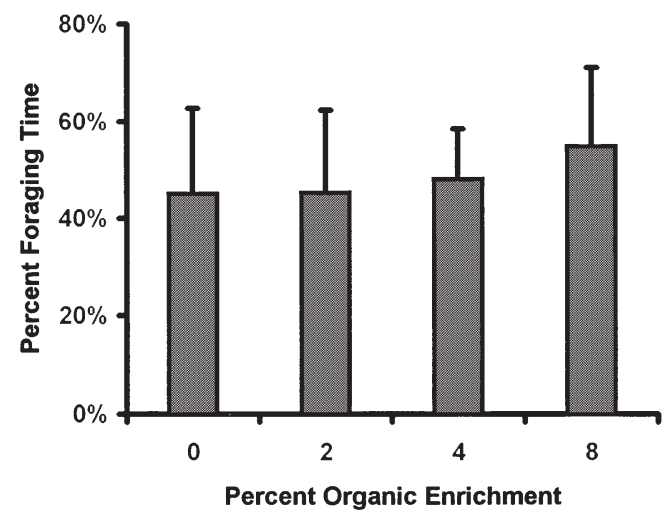

Fig. 1. Total foraging time in seconds versus percent organic enrichment of the worm's potential feeding area. Results are means and standard deviations. Eight replicates per treatment. Treatments were not significantly different from one another (Kruskal-Wallis, $\mathrm{p}=0.60$ )

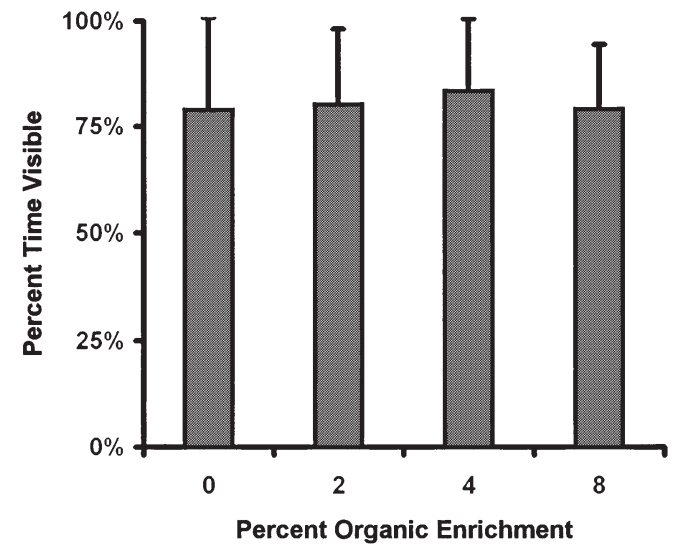

Fig. 2. Total time visible (s) as a function of percent organic enrichment. Results are means and standard deviations. Total time visible is the cumulative number of seconds that any portion of the worm's body (at least feeding tentacles) was exposed on the sediment surface. Observation periods were $1800 \mathrm{~s}$ in duration. Treatments were not significantly different from one another (Kruskal-Wallis, $\mathrm{p}=0.76$ )

observed, non-foraging behaviors (defecation, waving of palps above the sediment surface without contacting the surface, uncategorizable behaviors) did not change as a function of treatment (Kruskal-Wallis, $\mathrm{p}=$ $0.25)$ but were also quite variable. These behaviors constituted between 16 and $70 \%$ of the visible portion of the observation period.

As expected, the percentage of foraging time spent collecting on natural sediment reduced as sediment enrichment increased (Kruskal-Wallis, p < 0.05) (Fig. 3). Although the trend was as expected, only the 0 and $4 \%$ enrichments were significantly different (multiple comparison test, experimentwise error, $p<0.05)$. Contrary to expectations, the percentage of foraging time

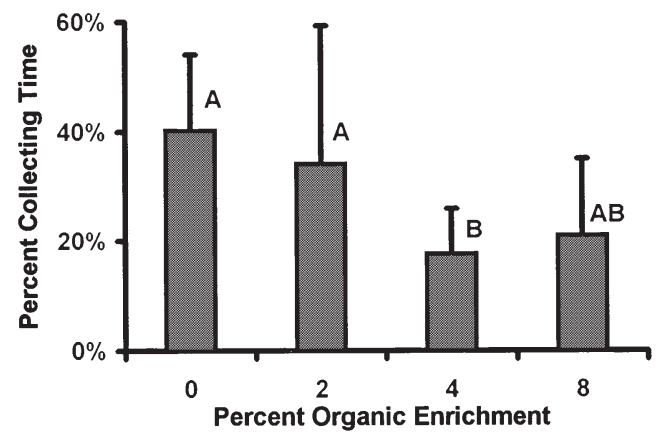

Fig. 3. Percentage of foraging time spent collecting on unaltered natural sediments per percent organic enrichment. Results are means and standard deviations. Collecting time on unaltered sediments is normalized by the total time that the individual was foraging and expressed as a percentage. Bars sharing a letter were not significantly different by a multiple comparison test (experimentwise error, $p<0.05$ ) 


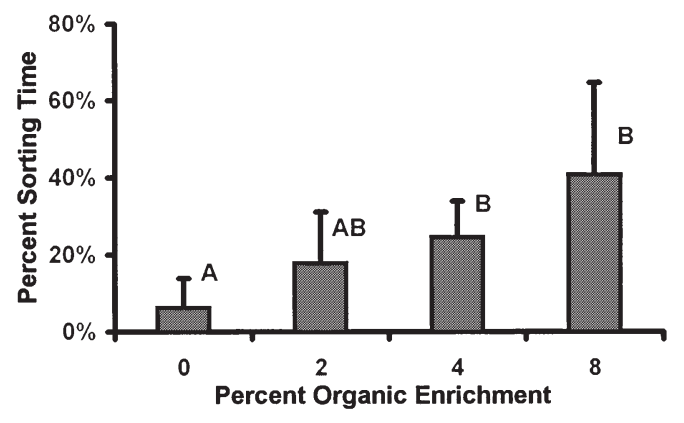

Fig. 4. Percentage of sorting time per percent organic enrichment. Sorting time is normalized by the total time that the individual was foraging and expressed as a percentage. Results are means and standard deviations. Bars sharing a letter were not significantly different by a multiple comparison test (experimentwise error, $\mathrm{p}<0.05$ )

spent collecting on enriched sediment did not increase as sediment enrichment increased (Kruskal-Wallis, $\mathrm{p}=$ 0.29). As expected, however, the percentage of foraging time spent sorting food items increased significantly as a function of organic enrichment (KruskalWallis, p < 0.005) (Fig. 4). The $0 \%$ organic addition treatment was significantly different from both the 4 and $8 \%$ treatments and the $2 \%$ treatment was intermediate (multiple comparison test, experimentwise error, $\mathrm{p}<0.05)$.

The percentage of foraging time that individuals exposed their anterior segments decreased significantly with increasing organic enrichment $(\mathrm{p}<0.05)$ (Fig. 5). By the multiple comparison test, the $0 \%$ treatment was significantly different from the 4 and $8 \%$ organic addition treatments, while the $2 \%$ treatment was intermediate (experimentwise error, $\mathrm{p}<0.05$ ).

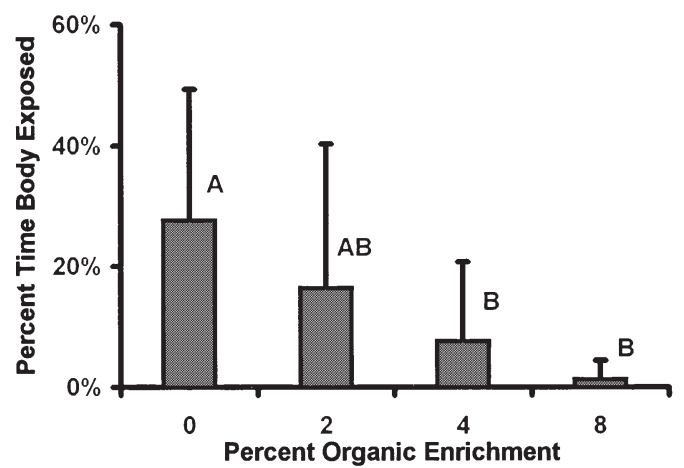

Fig. 5. Risky foraging time per organic enrichment. Results are means and standard deviations. Bars sharing a letter were not significantly different by a multiple comparison test (experimentwise error, $\mathrm{p}<0.05$ ). Risky foraging behavior is defined as exposure of the worm's anterior body segments beyond the tube mouth. Body exposure time is normalized by the total time foraging and expressed as a percentage

\section{DISCUSSION}

An early model for optimal foraging in sedentary deposit feeders focused on foraging with respect to maximizing net energy gain (Taghon 1978). The model predicted that deposit feeders would feed selectively on small, organically rich particles. The majority of the published data support this prediction; in general, deposit feeders selectively ingest smaller particles and particles of higher organic value (Taghon 1982, Taghon \& Jumars 1984, Clements \& Stancyk 1984, Jumars 1993).

Surface deposit feeders exploit a food resource which is both spatially and temporally variable. It is likely that the most energetically valuable food items are the newest and the least dense, which implies that they are also the most likely to be redistributed physically (Jumars 1993). The majority of surface deposit feeders have relatively fast gut passage times, which lends credence to the idea that only the most nonrefractory components are available to them, again these are likely to be the least dense and thus the most spatially and temporally variable (Jumars 1993, Mayer et al. 1997). Given the typical microphagous model of deposit feeding, the gut is expected to be where differentiation of refractory and non-refractory particles occurs; however, many deposit feeders differentiate among particles prior to ingestion, at least between glass beads with and without an organic coating (Taghon 1982, Clements \& Stancyk 1984), suggesting that they are not strictly microphagous. Given this, we expected Streblospio benedicti to distinguish areas of enrichment from unenriched sediments and to feed differentially in the enriched areas. As seen in Fig. 1, the percentage of the observation period devoted to all components of foraging by individuals did not differ significantly across treatments. As expected, individuals did significantly reduce the percentage of collecting time spent in areas of natural sediment when enriched sediments were simultaneously available (Fig. 3). There was not, however, a corresponding increase in the percentage of collecting time spent on the enriched sediments (Kruskal-Wallis, p = 0.29). Instead, with increases in organic enrichment, the percentage of foraging time devoted to sorting significantly increased (Fig. 4). This is the first study to show that a supposedly microphagous deposit feeder alters its foraging area and increases foraging effort on a small spatial scale. Apparently, as individuals encountered the enriched material, they rapidly brought large quantities to the mouth, necessitating a recognizable sorting step, a period during which the worms stopped bringing material to the mouth and appeared to sort the collected material at the mouth prior to ingestion. This was true even though the particle distributions 
did not differ between the enriched and natural sediments (paired $t$-test, $\mathrm{p}=0.40$ ). This suggests that given sediments enriched in detrital material, the worms rapidly collect and then hoard 'tasty' detrital particles, investing time sorting and then ingesting the choicest morsals in their cache. This type of feeding is not typical of microphagous feeders, but is common among macrophagous feeders.

The expectation from optimal foraging theory relates to the rate of energy gain (net energy per feeding time) not the amount of gain (Schoener 1971). Given organic enrichment and no change in the time foraging on the enriched material, the rate of gain is increased because the energy value (the numerator) is increased. Clearly, with organic enrichment, our experimental analogy for the arrival of new detrital material, collecting time on unenriched sediments decreased and sorting time increased significantly (Figs. $3 \& 4$ ). These observations are consistent with the view that surface deposit feeders differentially exploit temporally variable food resources. These are some of the first quantitative data to suggest that deposit feeders can differentially exploit food resources on a small spatial scale, although a number of studies have documented higher bulk feeding rates with enriched sediments (Jumars \& Self 1986, Karrh \& Miller 1994, Bock \& Miller 1999), and recently spionids have been shown to respond to simple dissolved cues (Ferner\& Jumars 1999). The results agree with the published data demonstrating the ability of surface deposit feeders to differentiate between particles with and without organic coatings (Taghon 1982). These observations also imply that given such behavioral sophistication, mean values of surface food conditions may be quite uninformative because these surface deposit feeders are selecting their feeding areas on a very small scale.

Although most of the work on optimal foraging theory has concentrated on behavior that maximizes net energy gain, the second tenet of the theory says that organisms will forage in such a way as to minimize predation risk. It is clear that the risk of tissue loss is extremely high for surface deposit feeders. It is not uncommon for more than $10 \%$ of a spionid population to be regenerating their feeding tentacles (Lindsay \& Woodin 1992), a costly process which reduces both growth rate and fecundity (de Vlas 1979, Zajac 1985, Bergman et al. 1988). Therefore, a reduction in foraging behavior with high predation risk would be advantageous.

The risk of mortality compounded by environmental circumstances puts tremendous selection pressures on organisms to forage in ways that reduce predation risk but maximize energy gain (MacArthur \& Pianka 1966). In our experimental protocol both enriched and unenriched sediments were adjacent to the individual's tube, within reach of its tentacles alone without extention of the body beyond the tube opening. If individuals could distinguish between enriched and unenriched sediments and recognize the enriched sediments as a high quality food source, then one would expect exposure of the body on the surface to decrease as level of organic enrichment increased. The results support this prediction (Fig. 5). Individuals exposed their anterior segments significantly less with organic enrichment.

Our behavioral observations of Streblospio benedicti therefore strongly suggest that it is capable of differentiating among food patches (Fig. 3), differentially exploiting them (Fig. 4), and reducing its exposure to predators while foraging (Fig. 5). This is consistent with designating $S$. benedicti as both an energy maximizer and a risk minimizer in terms of optimal foraging theory (MacArthur \& Pianka 1966). However, we have only addressed 1 aspect of this species' foraging behavior. These worms spend a considerable amount of their foraging time suspension feeding, and thus it is important to consider the application of these results to suspension feeding. As in deposit feeding, food quality is temporally and spatially variable for suspension feeders; thus, we would expect $S$. benedicti and comparable organisms to show parallel behavioral changes with changes in food quality while suspension feeding (see Bock \& Miller 1996, 1997).

Our results confirm and extend those on particle selection by organic coating, diet analysis by stable isotopes, and gut enzyme analysis (Taghon 1982, Hentschel 1998, Mayer et al. 1997 respectively) and strongly suggest that these organisms' behaviors, including selectivity (Figs. 3 \& 4), risk reduction (Fig. 5), and mobility (Wilson 1983), are extremely important components of their foraging. Clearly, surface deposit feeders are not bulk ingestors of surface sediments but rather modify their behavior on small spatial scales in both terms of foraging locale and sorting of material as well as risk as surface conditions change (Figs. 3 to 5 ).

Acknowledgements. We thank Anne Kitchell, Michael Grove, Jonathan Cowart, Kevin Fielman, and Courtney Richmond for assistance in both the field and the laboratory. The manuscript benefited from comments by P. DeCoursey, D. Wethey, M. Grove, C. Richmond, K. Fielman, B. Hentschel, S. Lindsay, and an anonymous reviewer. Financial support was provided by the Howard Hughes Foundation to R.L.K. and by EPAEPSCoR to S.A.W. This research was carried out as an undergraduate honors thesis for the South Carolina Honors College of the University of South Carolina. This is Belle W. Baruch Institute Contribution No. 1204.

\section{LITERATURE CITED}

Bergman MJN, Van der Veer HW, Karczmarski L (1988) Impact of tail-nipping on mortality, growth and reproduction of Arenicola marina. Neth J Sea Res 22:83-90 
Bock MJ, Miller DC (1995) Storm effects on particulate food resources on an intertidal sandflat. J Exp Mar Biol Ecol 187:81-101

Bock MJ, Miller DC (1996) Fluid flow and suspended particulates as determinants of polychaete feeding behavior. J Mar Res 54:565-588

Bock MJ, Miller DC (1997) Particle-bound organic matter as a cue for suspension feeding in tentaculate polychaetes. J Exp Mar Biol Ecol 215:65-80

Bock MJ, Miller DC (1999) Particle selectivity, gut volume, and the response to a step change in diet for deposit-feeding polychaetes. Limnol Oceanogr 44:1132-1138

Clements LAJ, Stancyk SE (1984) Particle selection by the burrowing brittlestar Micropholis gracillima (Stimpson) (Echinodermata: Ophiuroidea). J Exp Mar Biol Ecol 84: $1-13$

Dade WB, Jumars PA, Penry DL (1990) Supply-side optimization: maximizing absorptive rates. In: Hughes RN (ed) Behavioral mechanisms of food selection, NATO ASI Series, Vol G 20. Springer-Verlag, Berlin, p 531-556

Daniel WW (1990) Applied nonparametric statistics, 2nd edn. PWS-KENT Publishing Co, Boston

Dauer DM (1984) Functional morphology and feeding behavior of Streblospio benedicti (Polychaeta: Spionidae). In: Hutchings PA (ed) Proc First International Polychaete Conference, Sydney. Linnean Society of New South Wales, Sydney, p 418-429

DeGroot SJ (1971) On the interrelationships between morphology of the alimentary tract, food and feeding behaviour in flatfishes (Pisces: Pleuronectiformes). Neth J Sea Res 5:121-196

de Vlas J (1979) Secondary production by tail regeneration in a tidal flat population of lugworms (Arenicola marina) cropped by flatfish. Neth J Sea Res 13:362-393

Eckman JE, Nowell ARM (1984) Boundary skin friction and sediment transport about an animal-tube mimic. Sedimentology 31:851-862

Ferner MC, Jumars PA (1999) Responses of deposit-feeding spionid polychaetes to dissolved chemical cues. J Exp Mar Biol Ecol 236:89-106

Hentschel BT (1996) Ontogenetic changes in particle-size selcetion by deposit-feeding spionid polychaetes: the influence of palp size on particle content. J Exp Mar Biol Ecol 206:1-24

Hentschel BT (1998) Intraspecific variations in $\delta^{13} \mathrm{C}$ indicate ontogenetic diet changes in deposit-feeding polychaetes. Ecology 79:1357-1370

Holling CS (1959) The components of predation as revealed by a study of small mammal predation of the European pine sawfly. Can Entomol 91:293-300

Jumars PA (1993) Gourmads of mud: diet selection in marine deposit feeders. In: Hughes RN (ed) Diet selection: an interdisciplinary approach to foraging behavior. Blackwell Scientific Publications, London, p 124-156

Jumars PA, Self RFL (1986) Gut-marker and gut-fullness methods for estimating field and laboratory effects of sediment transport on ingestion rates of deposit feeders. J Exp Mar Biol Ecol 98:293-310

Karrh RR, Miller DC (1994) Functional response of a surface-deposit feeder, Saccoglossus kowalevskii. Limnol Oceanogr 39:1455-1464

Karrh RR, Miller DC (1996) Effect of flow and sediment transport on feeding rate of the surface-deposit feeder Sac- coglossus kowalevskii. Mar Ecol Prog Ser 130:125-134

Lehmann EL (1975) Nonparametrics: statistical methods based on ranks. Holden-Day Inc, San Francisco

Lindsay SM, Woodin SA (1992) The effect of palp loss on feeding behavior of two spionid polychaetes: changes in exposure. Biol Bull 183:440-447

Lindsay SM, Woodin SA (1995) Tissue loss induces switching of feeding mode in spionid polychaetes. Mar Ecol Prog Ser 125:159-169

Lopez GR, Levinton JS (1987) Ecology of deposit-feeding animals in marine sediments. Q Rev Biol 62:235-260

MacArthur RH (1972) Geographical ecology: patterns in the distribution of species. Harper \& Row, New York

MacArthur RH, Pianka ER (1966) On optimal use of a patchy environment. Am Nat 100:603-609

Mayer LM, Jumars PA, Taghon GL, Macko SA, Trumbore S (1993) Low-density particles as potential nitrogenous foods for benthos. J Mar Res 51:373-389

Mayer LM, Schick LL, Self RFL, Jumars PA, Findlay RH, Chen Z, Sampson S (1997) Digestive environments of benthic macroinvertebrate guts: enzymes, surfactants and dissolved organic matter. J Mar Res 55:785-812

Miller DC, Jumars PA, Nowell AR (1984) Effects of sediment transport on deposit feeding: Scaling arguments. Limnol Oceanogr 29:1202-1217.

Schoener TW (1971) Theory of feeding strategies. Annu Rev Ecol Syst 2:369-404

Self RFL, Jumars PA (1978) New resource axes for deposit feeders? J Mar Res 36:626-641

Self RFL, Jumars PA (1988) Cross phyletic patterns of particle selection by deposit feeders. J Mar Res 46:119-143

Shimeta J (1996) Particle-size selection by Pseudopolydora paucibranchiata (Polychaeta: Spionidae) in suspension feeding and in deposit feeding: influences of ontogeny and flow speed. Mar Biol 126:479-488

Sun L, Perdue EM, Meyer JL, Weis J (1997) Use of elemental composition to predict bioavailability of dissolved organic matter in a Georgia river. Limnol Oceanogr 42:714-721

Taghon GL (1978) Predicting particle selection by deposit feeders: a model and its implications. Limnol Oceanogr 23: $752-759$

Taghon GL (1982) Optimal foraging by deposit-feeding invertebrates: roles of particle size and organic coating. Oecologia 52:295-304

Taghon GL (1988) The benefits and costs of deposit feeding in the polychaete Abarenicola pacifica. Limnol Oceanogr 33: 1166-1175

Taghon GL (1992) Effects of animal density and supply of deposited and suspended food particles on feeding, growth and small-scale distributions of two spionid polychaetes. J Exp Mar Biol Ecol 162:77-95

Taghon GL, Greene RR (1990) Effects of sediment-protein concentration on feeding and growth rates of Abarenicola pacifica Healy et Wells (Polychaeta: Arenicolidae). J Exp Mar Biol Ecol 136:197-216

Taghon GL, Jumars PA (1984) Variable ingestion rate and its role in optimal foraging behavior of marine deposit feeders. Ecology 65:549-558

Wilson WH Jr (1983) The role of density dependence in a marine infaunal community. Ecology 64:295-306

Zajac RN (1985) The effects of sublethal predation on reproduction in the spionid polychaete Polydora ligni Webster. J Exp Mar Biol Ecol 88:1-19 